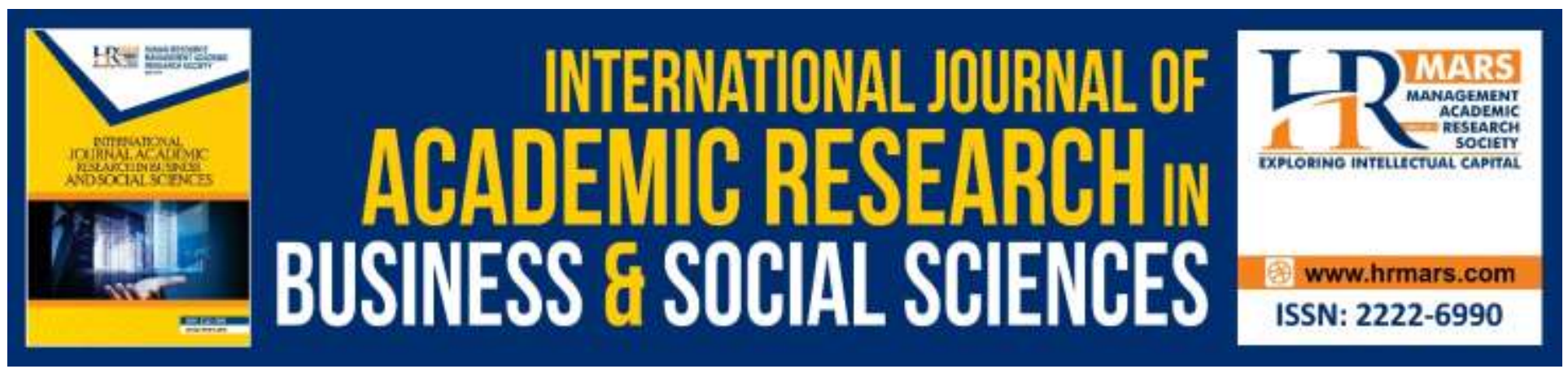

\title{
A Paradox Matrix of Organizational Strategy and Implementation of Workforce Diversity Policies
}

Catherine Kathure Kaimenyi

To Link this Article: http://dx.doi.org/10.6007/IJARBSS/v10-i1/6820

DOI:10.6007/IJARBSS/v10-i1/6820

Received: 27 December 2019, Revised: 01 January 2020, Accepted: 15 January 2020

Published Online: 30 January 2020

In-Text Citation: (Kaimenyi, 2020)

To Cite this Article: Kaimenyi, C. K. (2020). A Paradox Matrix of Organizational Strategy and Implementation of Workforce Diversity Policies. International Journal of Academic Research in Business and Social Sciences, 10(1), 144-160.

Copyright: (c) 2020 The Author(s)

Published by Human Resource Management Academic Research Society (www.hrmars.com)

This article is published under the Creative Commons Attribution (CC BY 4.0) license. Anyone may reproduce, distribute, translate and create derivative works of this article (for both commercial and non-commercial purposes), subject to full attribution to the original publication and authors. The full terms of this license may be seen

at: http://creativecommons.org/licences/by/4.0/legalcode

Vol. 10, No. 1, 2020, Pg. 144 - 160

http://hrmars.com/index.php/pages/detail/IJARBSS

JOURNAL HOMEPAGE

Full Terms \& Conditions of access and use can be found at http://hrmars.com/index.php/pages/detail/publication-ethics 


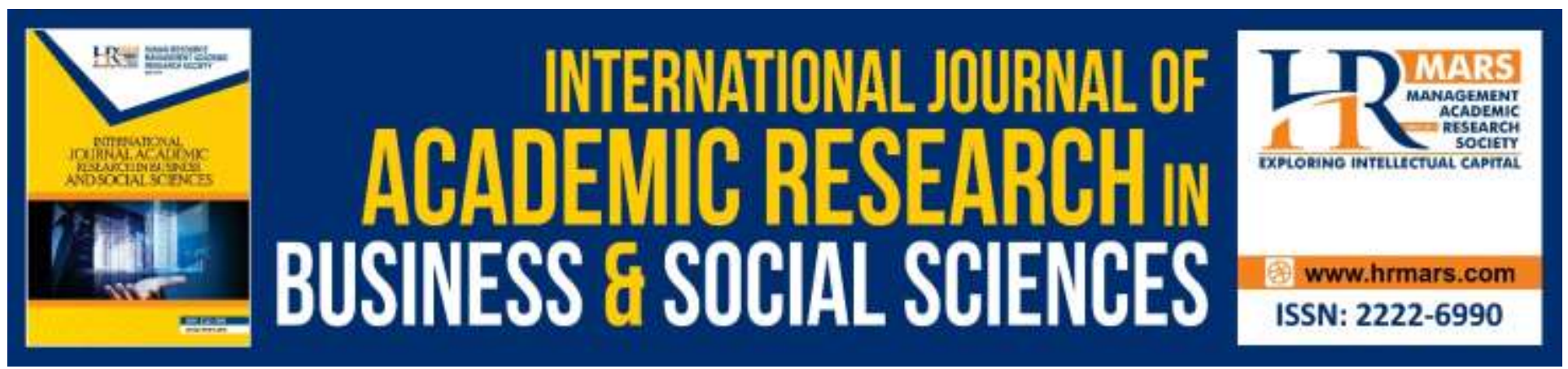

\title{
A Paradox Matrix of Organizational Strategy and Implementation of Workforce Diversity Policies
}

\author{
Catherine Kathure Kaimenyi \\ Lecturer, Chuka University, Department of Business Administration \\ Email: ckaimenyi@gmail.com
}

\begin{abstract}
This study sought to establish the influence that a diversity responsive organizational strategy has on the implementation of workforce diversity policies in Public Universities in Kenya. A positivist paradigm using descriptive cross sectional survey research design was used. The population of the study comprised of employees of 22 Public Universities in Kenya that existed prior to December, 2014. Purposive sampling was used to select seven universities that participated in the study while Yamane's (1967) formula was used to calculate the sample size. A sample size of 393 was used. A structured questionnaire with Likert-type interval scale anchored on a five-point scale was developed to collect primary data. Descriptive statistics of mean and standard error were calculated for the respective variables through use of Statistical Package for Social Science (SPSS) Version Nineteen. Inferential statistics were used to test the significance of the overall model at $95 \%$ level of significance. Contrary to the study expectations, streamlining of diversity policies in organizational strategy is seen to negatively influence the rate at which the institutions implement such policies. The study recommends for further research that adopts a time series design aimed at gathering continuous data to monitor organizational strategies by public universities and their effect on the already developed diversity policies particularly as stipulated in the Constitution of Kenya.
\end{abstract}

Keywords: Workforce Diversity, Policies, Organizational Strategy, Policy Implementation

\section{Introduction}

\section{Background of the Study}

The world has over the years witnessed increased diversity at the workplace which has created a need for management to give keen thought on workforce diversity policies. Workforce diversity means that people have differences in various perspectives key among them being primary dimensions like gender, ethnicity, culture, age, disability, religion, social status and personality traits (Schermerhorn, Hunt \& Richard, 2005, Reece \& Brandt, 1993). It also incorporates secondary characteristics like disparities in income, education religious beliefs and parental status). 
The issue of workforce diversity is a phenomenon which affects all nations around the world. As such various instruments for inclusiveness at the workplace have been developed to promote workforce diversity globally, regionally at the national level. For example, the International Labour Organization (ILO) outlines the need for equality and justice in employment regardless of the person's background. Instruments like the Beijing Platform for Action (BPFA, 1995) and the Convention on the Elimination of all Forms of Discrimination against Women (CEDAW, 1979) are all United Nations (UN) tools aimed at promoting gender equality at all levels in member states.

Despite all these efforts through policies, regulatory requirements and declarations to promote workforce diversity, there exist gaps in the implementation stage. Literature has tried to offer explanations as to why policy implementation is faced with challenges. This study has singled out the role of organizational strategy in implementation of workforce diversity policies in public universities in Kenya.

\section{Workforce Diversity}

Workforce diversity management has been defined in different ways. In broad terms, it includes primary and secondary dimensions. The primary dimension include static characteristics like age, race, ethnicity and gender. Secondary dimension comprises distinctiveness that can be changed such as income, education and religious beliefs. Schermerhorn, Hunt \& Richard, 2005; and Reece \& Brandt, 1993). This study is concerned with the primary dimensions of workforce diversity in public universities in Kenya and singles out ethnicity, gender and persons with disability as key areas of study. This is because these dimensions have been expressively captured as key in the Constitution.

Attention to workforce diversity practices in Kenya was fueled by the awakening of communities and the need for representation and equal opportunities and resources, and climaxed in 2008 after the chaos that followed the 2007 contested general elections. It was due to those chaos that the $\mathrm{NCIC}$ was established to spearhead unity, with the mandate to ensure ethnic workforce diversity in public employment including universities. Research in the area of diversity management such as that of Kibaji (2010) has established that negative ethnicity and intolerance have been a major weakness in the management of the universities. Section 7 of the NCl Act, 2008 stipulates that workforce in public institution should not comprise of more than a thirty per cent from the same community.

\section{Organizational Strategy}

In today's knowledge economy, workforce diversity hiring is quickly becoming an organizational strategy for competitive advantage. The business case for workforce diversity recruiting has been strengthened by studies linking workforce diversity to organizational performance. Many organizations view workforce diversity recruitment as a business strategy (Aoife, Edel, Denise, Rousseau \& Patrick, 2013). These authors identify a number of recruitment strategies; among them the knowledge-based employment and job-related employment. Organizations would consider workforce diversity recruitment if it makes business sense. Lockwood (2005) identifies four reasons for strategic workforce diversity recruiting as innovation and informed decision making, representation, improved public image and wider markets. 


\section{Public Universities in Kenya}

The genesis of public universities in Kenya dates back in 1956 when the Royal Technical College was established in Nairobi. Following a 1961 Act of the East African Commission, the Royal Technical College was converted to Nairobi College (now University of Nairobi). Other more universities including the private ones emerged as the need for higher education intensified. As Kenya becomes more sophisticated and with mounting numbers from diverse communities, races, religious backgrounds and other workforce diversity dimensions assessing higher education, it is paramount that a diverse workforce is inevitable. Zusman (2005); Yatin, Hamid, Shah, \& Hassan (2018); Shbeilat, Al Harasees (2018) recognized that universities of the 21st century experience philosophical challenges to the nature, values, and control of universities. Strictly adhering to the set policies such as that stipulating workforce diversity composition will not only help reduce conflict but also give universities a competitive edge in the market.

\section{Statement of the Problem}

A diverse workforce has been commended for its potential to create organizational harmony, improve productivity and assist the understanding of greater customer needs. In its efforts to leverage these benefits, the government of Kenya has developed policies which should guide staffing procedures. However, the implementation of such policies is still unexplored. Organizational strategy play a crucial role in the implementation of such workforce diversity policies. Yet despite the large number of studies conducted in the area of workforce diversity in Kenya, little exists exploring the role played by organizational strategy. For instant, there are those studies focusing on challenges of managing diverse workforce (Heike, Edeltraud \& Gumato, 2011), importance of managing workforce diversity (Tabitha., et. al. 2013) and effects of workplace workforce diversity management on organizational effectiveness (Otike, Omboi \& Mwalekwa, 2011). This study therefore seeks to bridge the gap by examining the influence of organizational strategy on implementation of workforce diversity policies in public universities in Kenya.

\section{Research Objectives}

1. To explore the relationship between streamlining workforce diversity policies with organizational strategy and implementation of workforce diversity policies in public universities in Kenya

2. To establish the relationship between perceived productivity of a diverse workforce and implementation of workforce diversity policies in public universities in Kenya

\section{Hypothesis}

$\mathrm{HO}_{1} \quad$ There is no significant relationship between streamlining workforce diversity policies with organizational strategy and implementation of workforce diversity policies in public universities in Kenya

$\mathrm{HO}_{2}$ There is no significant relationship between perceived productivity of a diverse workforce and implementation of workforce diversity policies in public universities in Kenya 


\section{Theoretical Review}

The study of workforce diversity today has stimulated discussion among scholars in human resource management. The term workforce diversity entered into human management literature in $1980 \mathrm{~s}$ as the United States responded to demographic changes within the workforce and global completion through diversity management. It was also a reaction to the introduction of equity legislation and practices. It is widely acknowledged (Konrad, 2003; Kelly \& Dobbin, 1998) that a major impetus to its development was a government commissioned report entitled Workforce 2000 (Johnston \& Packer 1987), which examined the changing demographics of the US workforce. Johnston and Packer (1987)) pointed out that, in the years between 1987 and 2000, the workforce would become older, more feminized and more disadvantaged as only 15 percent of the new entrants to the labor force would be native white males, compared to 47 percent in that category in 1987 . They stressed the need for national investment in education and training, along with changes in the organization of work and working conditions to accommodate the needs of women workers, minority workers of Blacks and Hispanics origin, people with disability and the aging population. Diversity management addresses both workforce diversity and social justice issues.

Theoretical underpinning for the study was drawn from the field of Diversity Management. They include Rawls's Theory of Justice (1971), Equity Theory (1965), Social Identity Theory (1979) and Policy Implementation Model (Pressman \& Wildavsky, 1973). These theories form the foundation of diversity and lays ground for the understanding of issues of workforce diversity polices and consequently implementation of such policies.

\section{Research Methodology}

\section{Research Paradigm and Design}

The study adopted a positivist paradigm which Creswell (2009), describes as quantitative in nature and based on rigid rules of logic measurements, truth, absolute principles and prediction. This paradigm is appropriate for this study because of its objectivity and use of quantitative research methodology to measure perceptions, attitudes and opinions about workforce diversity. It also utilizes a descriptive cross sectional survey research design as it affords the opportunity to capture population's characteristics and test hypotheses. Consequently, the researcher has no control on the variables thus cannot manipulate them making it inappropriate to use other research designs such as experimental research design (Kothari, 2003).

\section{Target Population}

The target population for this study comprises of all public universities in Kenya. The public universities were preferred since their structures are well defined and are likely to exhibit elaborate relationships among the study variables. Moreover, a NCIC (2012) study had revealed massive imbalances in workforce diversity which were of interest to the researcher. Respondents were selected from both the academic and non-academic staff from the universities that form the unit analysis in this study. The total population for the 22 public universities' workforce as per the 2014 statistics was about 25,000. 


\section{Sampling Procedure and Sample Size}

The first stage of sampling was to select the public universities that will form part of the study. This was done using purposive sampling. Seven universities namely University of Nairobi (UoN), Kenyatta University (KU), Jomo Kenyatta University of Agriculture \& Technology (JKUAT, Maseno University, Moi University, Egerton University and Maside Muliro University of Science and Technology (MMUST) were purposively selected. The second stage of sampling was to indentify respondents from the selected seven universities. The sample size was calculated using sample formula by Yamane (1967) as below:

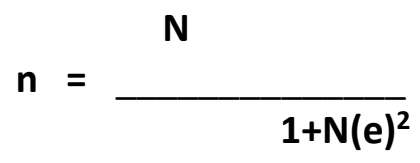

Where " $\mathrm{n}$ " is the sample size, " $\mathrm{N}$ " is the population size and " $\mathrm{e}$ " is the level of precision at 95\% confidence level with an error 5\%. A sample of 393 was selected which included 125 and 268 individuals from academic and non-academic staff respectively.

\section{Research Instruments}

The study used both primary and secondary data. The sources of primary data included individuals who provided information when interviewed, administered questionnaires or observed. The questionnaire was the key instrument for the research. Secondary data was derived from universities websites, journal articles, books, periodicals, government publications, media reports and Acts of Parliament among others. Data about gender and disability composition was accessed from existing information in the human resources records. Such secondary data was triangulated with primary data to ascertain the level of implementation.

\section{Data Collection and Analysis}

Data was collected using questionnaires. The following research model was adopted for this study; IWDP $=\beta_{0}+\beta_{1} X_{1}+\beta_{2} X_{2}+e$ In function form this model can be expressed as follows:

IWDP $=f\left(X_{1}, X_{2}, e\right)$

Where

IWDP = Implementation of Workforce Diversity Policies

$\mathrm{X}_{1} \quad=$ Mainstreaming of diversity policies in strategy

$\mathrm{X}_{2} \quad=$ Perceived productivity

$\beta_{\mathrm{o}}=$ Constant

$\beta_{\mathrm{i}} \quad=(\mathrm{i}=1,2,3,4)=$ regression coefficient at ith variable

e $\quad=$ Error Term (the error is normally distributed with a mean of zero and a variance of one)

\section{Results and Discussion}

The response rate for the study was $94 \%$ which was considered adequate for the study. 


\section{Descriptive Statistics}

The study explored the means and standard deviations (SD) of variables studied which included independent variables of contextual factors and moderating variable of stereotype. Statements were anchored on a five point Likert scale ranging from 1= Strongly Disagree to 5=Strongly Agree. Mean scores of sub-set statements as well as the aggregate averages were computed. A mean score of 2.5 indicated an average rating while means above or below represented a high or low measures in descending or ascending order respectively. Standard deviation was also computed as a measure of variations from the mean. A small SD indicates that most of the sample means lies near the middle while a large SD implies that the sample mean is spread out over a large rate of values (Harper, 2000). As opposed to large SD, small SD is a good estimator of the population mean.

\section{Streamlining of Diversity in Organizational Strategy}

Streamlining of diversity in organizational strategy was indicated to measure the degree to which universities anchored workforce diversity policies in their organizational strategies. This was based on the premise that where policies are underscored and aligned to the broad strategy of the organizations, they are likely to be implemented to a large extend. To establish the level at which diversity is anchored on strategy, a set of six items was developed. Results are presented in Table 4.1

Table 4.1: Respondents Scores on Streamlining Diversity with Strategy

\begin{tabular}{|c|c|c|c|}
\hline Streamlining Diversity with Strategy Statements & $\mathbf{N}$ & Mean & SD \\
\hline $\begin{array}{l}\text { Policies on employment balance to promote a diverse } \\
\text { workforce are well documented }\end{array}$ & 368 & 3.88 & .091 \\
\hline $\begin{array}{l}\text { One gender is more strategically aligned to the universities } \\
\text { objectives }\end{array}$ & 362 & 1.78 & .077 \\
\hline $\begin{array}{l}\text { Employees from some ethnic communities are opposed to key } \\
\text { organizational growth strategies }\end{array}$ & 357 & 4.36 & .071 \\
\hline $\begin{array}{l}\text { Workforce diversity policies are operational in my } \\
\text { organization }\end{array}$ & 351 & 1.80 & .080 \\
\hline $\begin{array}{l}\text { The university has no business in hiring minorities who will } \\
\text { not help in achieving its strategic goals }\end{array}$ & 345 & 4.50 & .066 \\
\hline $\begin{array}{l}\text { The minority groups do not feature in my organization's } \\
\text { strategic plan }\end{array}$ & 349 & 4.46 & .066 \\
\hline Composite Mean Score & 355 & 3.46 & .075 \\
\hline
\end{tabular}

The findings in Table 4.1 indicate that to a large extent workforce diversity policies are streamlined with organizational strategy (mean $=3.46, S D=0.075)$. This implies that the strategic plans of the institutions have incorporated strategies for making the organizations diverse in terms of gender, ethnic and disability. It can also be interpreted to mean that policies on those perspectives are available in the universities. The findings further reveal that workforce diversity policies are poorly (mean=1.8, SD=0.8) operational in universities implying that the institutions may have developed polices for mere compliance leaving diversity just at the policy level. There was also strong 
disagreement with the statement that one gender is strongly strategically aligned than the other to the institutions objectives (mean=1.78, SD=0.077). This agrees with the views of Oladipo \& Abdulkadir (2011) that no gender differences exist in attainment of organizational goals and mission.

\section{Respondents Scores on Perceived Productivity}

Productivity was indicated by the perceived organizational output using dimensions of gender, ethnic and persons with disabilities. This was based on the premise that diversity which is marked with heterogeneous workforce is likely to produce better output compared to a homogenous workforce. To establish the perceived level of output, six items were developed. Results are presented in Table 4.2

Table 4.2 Scores on Productivity

\begin{tabular}{|c|c|c|c|}
\hline Productivity Statements & $\mathbf{N}$ & Mean & SD \\
\hline $\begin{array}{l}\text { Employees from some communities are hindrances to the } \\
\text { achievement of the University's objectives }\end{array}$ & 346 & 4.50 & .063 \\
\hline $\begin{array}{l}\text { The more a workforce is diverse the greater the } \\
\text { productivity }\end{array}$ & 357 & 1.75 & .074 \\
\hline $\begin{array}{l}\text { Persons with disability are a source of competitive } \\
\text { advantage }\end{array}$ & 345 & 1.68 & .073 \\
\hline $\begin{array}{l}\text { It is difficult to create a shared vision when the workforce } \\
\text { is diverse }\end{array}$ & 336 & 4.57 & .063 \\
\hline $\begin{array}{l}\text { The mere act of bringing in the minorities in the } \\
\text { organization does not translate to any benefit }\end{array}$ & 350 & 4.41 & .071 \\
\hline $\begin{array}{l}\text { The level of customer satisfaction declines with increasing } \\
\text { workforce diversity }\end{array}$ & 358 & 1.75 & .074 \\
\hline Composite Mean Score & 349 & 3.11 & .070 \\
\hline
\end{tabular}

Findings in Table 4.2 indicate that to a large extent a diverse workforce is associated with high productivity (mean=3.11, SD=0.070). This indicates that a diverse workforce provides the synergy that impels employees to increase their efforts. The employer would thus employ a diverse workforce to tap from this benefits. Most of the respondents however indicated that the mere act of bringing in the minorities in the organization does not translate to any benefit (mean=4.41, SD=0.71). This supported Liswood (2010) studies that it is not enough to create a corporate version of 'Noah's Ark' in bringing in two of each kind unless the organization engages them to benefit from their diverse perspectives. It was also indicated that to a great extent (mean 4.50, SD=0.63) employees from some communities are hindrances to the achievement of the University's' objectives. The lowest mean score (mean=1.68, SD=0.073) was about persons with disabilities which may indicate why organizations may not be keen to employ people of this category. 
INTERNATIONAL JOURNAL OF ACADEMIC RESEARCH IN BUSINESS AND SOCIAL SCIENCES

Vol. 10, No. 1, Jan, 2020, E-ISSN: 2222-6990 @ 2020 HRMARS

Table 4.3 Summary of Organization Strategy

\begin{tabular}{lrrr}
\hline Organizational Strategy & N & Mean & SD \\
\hline Streamlining of diversity with strategy & 355 & 3.46 & 0.075 \\
Perceived Productivity & 349 & 3.11 & 0.07 \\
\hline Composite Mean Score & $\mathbf{3 5 2}$ & $\mathbf{3 . 2 8 5}$ & $\mathbf{0 . 0 7 2 5}$ \\
\hline
\end{tabular}

Results in Table 4.3 reveals that the average mean scores of organizational strategy was 3.285, $\mathrm{SD}=0.0725$. The results indicate that a comprehensive organizational strategy is perceived to a large extent to be beneficial to an organization (mean=3.11) as well being well inclusive to include policies that address workforce diversity issues (mean=3.46, SD=0.075). From these results, there is an expectation that the degree of implementation of workforce diversity policies increases.

\section{Implementation of Workforce Diversity Policies}

This study identifies ethnic composition, gender and physical ability/disability dimensions as indicators for the degree to which workforce diversity policies have been implemented.

\section{Ethnic Composition}

Ethnicity is used interchangeably with tribalism to mean a group of people who share the same culture and identity including language, geographical location and behaviour norms and attitude (Cybulski, 2005). To measure the ethnic composition in public universities, five items were developed where respondents were asked to state how strongly they agreed with related statements. Results are presented in Table 4.4.

Table 4.4: Respondents mean Scores on Ethnic Composition of the Workforce

\begin{tabular}{lccc}
\hline Ethnic Composition & N & Mean & \multicolumn{1}{c}{ SD } \\
\hline $\begin{array}{l}\text { No single community has more than 30\% representation in } \\
\text { the University's workforce }\end{array}$ & 372 & 2.13 & .079 \\
$\begin{array}{l}\text { The university has maintained the regional balance in its } \\
\text { employment over the last five years }\end{array}$ & 368 & 2.05 & .075 \\
$\begin{array}{l}\text { Unrepresented communities have been given priority for } \\
\text { employment positions over the last five years }\end{array}$ & 365 & 1.97 & .074 \\
$\begin{array}{l}\text { Regional representation in the workforce is satisfactory } \\
\text { The university workforce reflects the face of Kenya }\end{array}$ & 364 & 1.89 & .074 \\
\hline Composite Mean Score & 372 & 1.91 & .072 \\
\hline
\end{tabular}

Results in Table 4.4 show that the average mean score for ethnic composition of the workforce is $1.99, \mathrm{SD}=.074$. Generally the mean scores of all items are below average ranging from the highest mean score of $2.13, \mathrm{SD}=.079$ to the lowest mean score of $1.89, \mathrm{SD}=-074$. This means that public universities are perceived to have a workforce that does not reflect the face of Kenya as far as ethnicity is concerned. The results are consistent with the NCIC (2012) study which revealed a huge 
tribal imbalance in public universities in Kenya. This suggests that policies of inclusivity on ethnic dimensions are poorly implemented.

\section{Gender and Disability Proportion}

Gender representation was indicated by the ratio of men to women. Regulatory requirements stipulate that no more than two-thirds (33\%) of the workforce should be of the same gender in any public organization. Absolute data on the ratio of women to men was collected from the respective universities as percentages. The scale used meant that an institution where either gender accounted to $0-10 \%$ was ranked as very poor, $(11-20) \%=$ poor, $(21-30) \%$ as fair, $(31-40) \%=$ good while those with (41-50) were ranked as very good. This scale was then converted to a five point likert scale from 1-5 in ascending order. It was then aggregated and average mean scores calculated. Results are presented in Table 4.5

Table 4.5 Mean Scores of Gender and Disability Representation

\begin{tabular}{llll}
\hline Gender and Disability & N & Mean & SE \\
\hline Gender Representation & 374 & 2.98 & 0.066 \\
Disability proportion & 373 & 1.99 & 0.028 \\
\hline
\end{tabular}

Results in Table 4.5 indicate a fair gender representation public universities (mean=2.98, SD =0.066). This implies that the workforce fall within the regulatory requirement of the two-thirds gender policy (between $31-40 \%$ ). These results may imply that public universities are striving to comply with the two thirds gender policy because this is an improvement from Onsongo (2009) where female academic staff accounted for only about $26 \%$.

The mean score for persons with disability was poor (mean=1.99, SD=0.028) indicating that the institutions far below the minimum requirement of $5 \%$ stipulated by the Constitution. This could be attributed to the complexity and cost involved in implementing such policies. For example, diversity policies do not spell out the process that should be followed in recruitment of PWD or the explanation of who qualifies to be included in this category.

\section{Correlation Analysis Results}

Correlation analysis using Pearson Product moment correlation coefficient technique was used to establish the relationship between streamlined diversity policies in organizational strategy, perceived productivity of inclusive strategy and implementation of workforce diversity policies. Table 4.6 summarizes the results. 
Table 4.6 Correlation Analysis Matrix

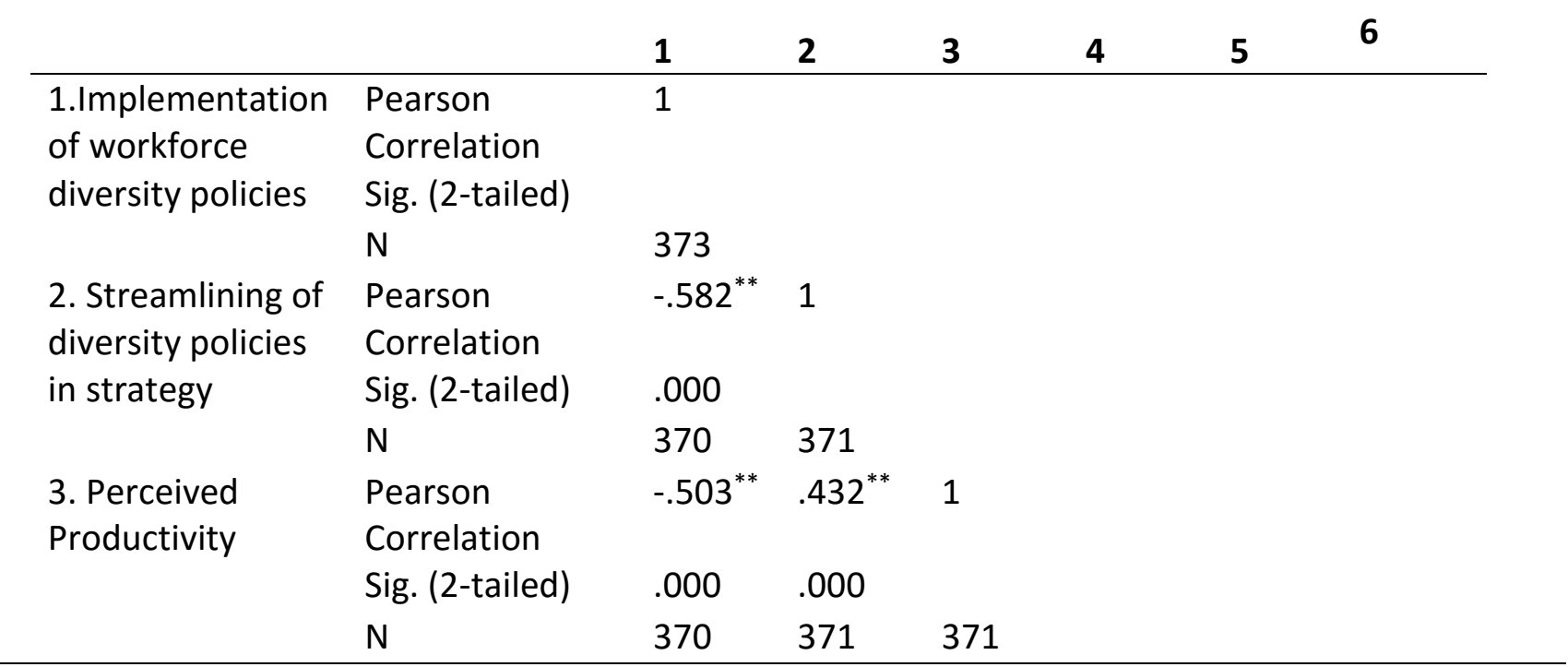

**. Correlation is significant at the 0.01 level (2-tailed).

The results in Table 4.6 indicate that the relationship between streamlining of diversity policies on strategy and implementation of WDP is moderate, negative and statistically significant $(r=-0.582, p-$ value $=0.000<0.05$ ). This implies that the more diversity policies are streamlined in the wider strategy of the organization, the less the organization implements such policies and vice versa.

\section{Hypothesis Testing}

This study was based on the premise that there is a relationship between organizational strategy and implementation of workforce diversity policies in public universities. Two hypotheses were developed in line with these relationships. To establish the statistical significance of the respective hypothesis, simple and multiple regression analysis were conducted at $95 \%$ confidence level.

\section{Streamlining of Diversity Policies and Implementation}

The first objective of the study led to the development of the following hypothesis which was tested:

\section{$\mathrm{HO}_{1} \quad$ There is no significant relationship between streamlining of workforce diversity polices and implementation of workforce diversity policies in public universities in Kenya}

The results are presented in Table 4.7 
INTERNATIONAL JOURNAL OF ACADEMIC RESEARCH IN BUSINESS AND SOCIAL SCIENCES

Vol. 10, No. 1, Jan, 2020, E-ISSN: 2222-6990 @ 2020 HRMARS

Table 4.7 Streaming of Workforce Diversity Policies and Implementation

(a) The Goodness-of-Fit

\begin{tabular}{|c|c|c|c|c|c|c|}
\hline & $\mathrm{R}$ & R Square & & Adjusted R Squa & & $\begin{array}{l}\text { ror of the } \\
\text { Estimate }\end{array}$ \\
\hline & $.582^{a}$ & .345 & & .34 & & 1.06176 \\
\hline & le Overall Si & ficance & & & & \\
\hline & & $\begin{array}{l}\text { Sum of } \\
\text { Squares }\end{array}$ & $d f$ & Mean Square & $\mathrm{F}$ & Sig. \\
\hline 1 & Regression & 216.654 & 1 & 216.754 & 192.199 & $.000^{\mathrm{a}}$ \\
\hline & Residual & 405.016 & 366 & 1.128 & & \\
\hline & Total & 621.670 & 367 & & & \\
\hline
\end{tabular}

(c) The Individual significance

\begin{tabular}{|c|c|c|c|c|c|c|}
\hline \multirow{2}{*}{\multicolumn{2}{|c|}{ Model }} & \multicolumn{2}{|c|}{$\begin{array}{c}\text { Unstandardized } \\
\text { Coefficients }\end{array}$} & \multirow{2}{*}{$\begin{array}{r}\begin{array}{c}\text { Standardized } \\
\text { Coefficients }\end{array} \\
\text { Beta }\end{array}$} & \multirow[b]{2}{*}{$\mathrm{T}$} & \multirow[b]{2}{*}{ Sig. } \\
\hline & & $B$ & Std. Error & & & \\
\hline 1 & (Constant) & 6.136 & .313 & & 20.153 & .000 \\
\hline & $\begin{array}{l}\text { Organization } \\
\text { strategy }\end{array}$ & -1.277 & .092 & -.582 & -13.864 & .000 \\
\hline
\end{tabular}

a. Dependent Variable: Implementation of workforce diversity policies

b. Independent Variable: Streamlining of diversity policies on strategy

The results in Table 4.7 show that streamlining of diversity polices on strategy had a statistically significant influence on implementation of workforce diversity policies and therefore the hypothesis is rejected. It explained a $34.5 \%$ of its variation $\left(R^{2}=0.345\right)$. The Regression coefficient value of the computed scores of organizational strategy was -1.277 with a t-test of -13.86 and a significant level of 0.000 . This implies that an increase in the degree to which workforce diversity policies are streamlined in strategy decreases the overall implementation level of workforce diversity policies. At the same time, the more profitable a diverse workforce is perceived, the less the degree of implementation of workforce diversity policies. These results are contrary to the findings of Lockwood's (2005) business case for diversity perspective, that for an organization to value and comply to diversity policies, it must offer tangible benefits. Consistent with Lockwood's findings (and contrary to the findings of this study) is Wilson \& Atlanta, (2009) whose studies established that higher operating results and a stronger stock price growth were major considerations for a gender diversity in organization. It was established that the overall significance in the model suggest that the regression was statistically significant at 5\% ( $F=192.2 ; P$-value $=0.000)$.

These findings portray a paradox scenario since they contradict predetermined expectations of the study. This is because the study hoped that where organizations have clear diversity policies that are included in their wider strategy, then such policies are likely to be implemented to a large extent. However some explanations may be offered to this. One, it is possible that institutions put workforce 
diversity policies in their strategy with good intentions but the spirit of interpretation is not to the tune. This would then limit commitment to the policy thereby leaving the policies just on paper. It can therefore be expressed as a cover-up, a strategy of concealment to prevent public suspicion and questions about institutions' workforce diversity agenda. Moreover, public universities are monitored for quality service delivery and so documentation is critical even when what is documented remains only at the blue print level.

\section{Perceived Productivity and Workforce Diversity Policies}

To establish the relationship between perceived productivity associated to inclusive policies and implementation of workforce diversity policies, a second relevant hypothesis was formulated as follows:

$\mathrm{HO}_{2}$ There is no significant relationship between perceived productivity associated to inclusive diversity policies and implementation of workforce diversity policies in public universities in Kenya

Results are presented in Table 8

Table 4.8: Organizational Culture and Workforce Diversity Policies

(a) Goodness-of-Fit

Std. Error of the

\begin{tabular}{cccc}
$\mathrm{R}$ & $\mathrm{R}$ Square & Adjusted R Square & Estimate \\
\hline $.503^{\mathrm{a}}$ & .387 & .392 & 1.01774 \\
\hline
\end{tabular}

(b) Overall Significance

\begin{tabular}{|c|c|c|c|c|c|c|}
\hline & Model & $\begin{array}{l}\text { Sum of } \\
\text { Squares }\end{array}$ & df & Mean Square & $\mathrm{F}$ & Sig. \\
\hline 1 & Regression & 250.597 & 1 & 250.597 & 241.937 & $.000^{a}$ \\
\hline & Residual & 381.173 & 368 & 1.036 & & \\
\hline & Total & 631.770 & 369 & & & \\
\hline c) 1 & Idividual Signifi & & & & & \\
\hline & & $\begin{array}{r}\text { Unstand } \\
\text { Coeffi }\end{array}$ & $\begin{array}{l}\text { dized } \\
\text { ents }\end{array}$ & $\begin{array}{c}\text { Standardized } \\
\text { Coefficients }\end{array}$ & & \\
\hline & & B & $\begin{array}{l}\text { Std. } \\
\text { Error }\end{array}$ & Beta & $\mathrm{t}$ & Sig. \\
\hline 1 & (Constant) & 7.091 & .331 & & 21.413 & .000 \\
\hline & $\begin{array}{l}\text { Organization } \\
\text { Culture }\end{array}$ & -1.528 & .098 & -.503 & -15.554 & .000 \\
\hline
\end{tabular}

a. Dependent Variable: Implementation of WDP

b. Independent Variable: Perceived productivity of inclusive policies on strategy

Results in Table 4.8 show a significant influence of perceived productivity on implementation of workforce diversity policies. The hypothesis is therefore rejected at $5 \%$ confidence level. Regression of aggregated mean score of implementation of workforce diversity policies against perceived 
productivity produced an $\mathrm{R}^{2}$ of 0.387 as shown in Table 4.32 . This implies that perceived productivity explained $38.7 \%$ of the variation in composite score for implementation of workforce diversity policies. These results have revealed a statistically significant negative relationship between perceived productivity associated with inclusive strategy and implementation of workforce diversity policies (Beta $=-0.503 ; \mathrm{P}$-value $=0.000$ ). The statistically significant negative relationship between perceived productivity and implementation of WDP suggest that perceived productivity influences implementation of WDP in public universities.

\section{Conclusions and Recommendations \\ Conclusion}

Despite being entrenched in the Constitution it is clear from the study findings that there is a great deal more work to be done to enhance understanding of the intended purpose of the policies, the implementation processes, underlying challenges and potential benefits. The study established concerns that the potential expense of accommodating a worker with a disability are a major barrier as it contributes to a substantial financial burden to an organization. Such perceived financial implications may extend to infrastructure related costs of making workplace accessible, increased premiums for health insurance or workers compensation, legal and financial risk should a workplace injury or accident occur, as well as indirect costs like as extra supervision or time needed to complete tasks.

The findings of the study revealed that a gender gap exists in public universities where female employees are the minority. This means that although gender diversity policies broadly aim at bringing affirmative action for either gender, it is obvious that at the time of this study, women are the focus of diversity policies. This will bring in more women in the mainstream and eventually lead to the long sought for gender equity at the workplace.

Strategy is crucial in focusing and guiding the focus and direction of every organization. As such every aspiration or commitment that an organization wish to make must be aligned to its strategy. To enhance implementation, policies must be reinforced by being anchored on organizational strategy, a move that seems to be in place in public universities. Interestingly, the study revealed that the more workforce diversity policies are anchored on strategy, the less they get implemented. Thus a conclusion is made that public universities may be hiding behind documenting diversity policies just to cover up and safeguard their images. It emerged from the study that organizational strategy in well inclusive spelling out how diverse it should be in line with the Constitution, yet the level of implementing such policies decline. Further, a conclusion is made that an institution that incorporates diversity policies in their organizational strategy is perceived to be one associated with high productivity. A general expectation is that where this is the case, such an organization should strive to ensure that it is inclusive, yet the study has proved otherwise. This is a paradox that requires further research!

This study contributes to theory and knowledge in the area of workforce diversity, policy and strategy development by cautioning policy makers on the danger of enforcing policies that the masses have 
no ownership about. There is need for participation so that stakeholder acceptability can be achieved.

\section{Recommendations}

Based on findings of the study, the following recommendations are made to policy makers at the national level, human resource practitioners in public universities and other public institutions.

Since organizational strategy in public universities emerged to have incorporated workforce diversity policies adequately, attention should be focused on policy implementation. Sensitization efforts should be intensified to show both the monetary and non-monetary benefits of an heterogeneous workforce as opposed to homogeneity. This is important because a strategy which is cost effective was indicated as popular.

The study further challenges researchers in the discipline of psychology to explore the implementation of diversity policies from that angle because ideally the problem of the homogeneity witnessed at the workplace is not due to lack of polices but rather policy implementation. The focus should now shift to the psychological thinking of the policy implementers.

\section{References}

Ali, S. (2006). Why Does Policy Fail? Understanding the Problems of Policy Implementation in Pakistan - A Neuro-Cognitive Perspective. International Studies in Educational Administration, 34(1), 120

Aoife, M. M., Edel, C., Denise, M., \& Patrick, C. F. (2013). Human Resource Management, 52, 2 , 289 - 310. doi:10.1002/hrm.21529

Bathseba, O. (2012). Barriers to participation of Women Students with Disabilities in University Education in Kenya. Journal of Postsecondary Education and Disability, 25(1), 65 - 79. Retrieved from http://files.eric.ed.gov/fulltext/EJ970020.pdf

Beijing Platform for Action. (1995). Retrieved from http://www.un.org/womenwatch/daw/beijing/platform/plat1.htm

Bryan, E., \& Varat, J. (2008). Strategies For Promoting Gender Equity in Developing Countries: Lessons, Challenges and Opportunities. Washington DC, Windrow: Wilson International centre for Scholars.

CEDAW. (1979). Retrieved from www.un.org.

Cooper, R. D. \& Schindler, S. P. (2006). Business Research Methods (9 ${ }^{\text {th }}$ ed.). New Delhi-India. McGrawHill Publishing Company.Creswell, J. W. (2009). Research Design: Qualitative and Mixed Methods Approaches. London: SAGE

CUE. (2013). Universities authorized to operate in Kenya. Retrieved from http://www.cue.or.ke/

Hammermesh, R. (1986). Making Strategies Work: How Senior Managers Produce Results. USA, John Wiley \& Sons.

Heike, M. K., Edeltraud, H. E. \& Gumato, U. (2011). Institutional Change: The impact of Kenya's new constitution on the workforce diversity of the public service sector. Retrieved from http://www.hbs.edu/faculty/conferences/ 
Ibua, M. P. (2014). The Influence of Institutional Factors and Job Related Attitudes on the Relationship Between Employee Empowerment and Performance of Public Universities in Kenya. (Doctoral Dissertation, University of Nairobi).

Johnson, G., \& Scholes, K. (1984) Exploring Corporate strategy. Prentice Hall International Jones, P. (2008). Communicating Strategy. Abington, Oxon, England. Gower Publishing Limited. Josephine, B. B. (2005). A lot of them thought I would not last there. African women \& career Advancement in Academic scientific careers. Journal of Technology Transfer, 30, 397-407.

Kibaji, E. (2010, June 24). Major Challenges: We need to rethink strategies on university Education. Daily Nation .p13.

Kinyanjui, S. (2013). Innovative Strategies for Managing Workforce diversity in Kenyan Leading Corporations in Present Global Scenario. International Journal of Business and Management, 8(15), 2-32. Retrieved from http://dx.doi.org/10.5539/ijbm.v8n15p20

Knouse, S. B. (2009). Targeted Recruiting for Workforce Diversity: Strategy, Impression Management, Expectations, and Workforce Diversity Climate. International Journal of Management, 26, $347-353$

Konrad, A. (2003). Special issue Introduction: Defining the Domain of Workplace Workforce Diversity Scholarship. Group and Organization Management, 28(1), 4-17.

Kothari, C. R. (2011). Research Methodology: Methods and Techniques. New Delhi: New Age International Publishers.

Kundu, S., \& Mor, A. (2017), "Workforce diversity and organizational performance: a study of IT industry in India", Employee Relations, 2(39), 160-183. https://doi.org/10.1108/ER-06-20150114

Liswood, L. (2010). Moving beyond Workforce Diversity While Embracing Differences to achieve Success at Work. Hoboken, New Jersey: John Wiley \& Sons, Inc.

Lockwood, N. R. (2005). Workplace Workforce Diversity: Leveraging the Power of Difference for competitive advantage. SHRM Research Quarterly, 2, 9-15.

Loden, M., \& Rosener, J. (1991). Workforce America!: Managing Employee Workforce Diversity as a Vital Resource. Homewood, IL: Business One Irwin.

Makinde, T. (2005). Problems of Policy Implementation in Developing Nations: The Nigerian Experience. Journal of Social Sciences, 11(1), 63-69

Mendonca, M., \& Kanungo, R. N. (2007). Ethical Leadership: Work and Organizational Psychology. New York: Open University Press.

Munjuri, M. G., \& Maina, R. M. (2013). Workforce Diversity and Employee Performance in the National Cohesion and Integration Act. (2008)

NCIC. (2016). Tribalism Shock at Universities. Daily Nation .p4-5.

Oladipo, J. A., \& Abdulkadir, D. (2011). Strategic Human Resource Management and Performance in the Nigerian Manufacturing Sector: an Empirical Investigation. International Journal of Business Management. Doi:5539/ijbm.v6n9p46.

Employee characteristics and Employee Outcomes in Public Corporations in Kenya. (Unpublished. PhD Thesis. University of Nairobi) 
Onsongo, J. K. (2011). Promoting Gender Equity in Selected Public Universities in Kenya, OSSREA. Retrieved from https://books.google.co.ke/books

Otike, F. W., Omboi, B. M. \& Mwalekwa, F. K. (2011). Effects of Workplace Workforce Diversity Management on Organizational Effectiveness: a case study. European Journal of Business and Management, 3(2), 50 - 64.

Pressman, J. L., and Wildavsky, A. B. (1973). Implementation: How Great Expectation in Washington are Dashed in Oakland; or Why it's Amazing that Federal Program Works at all. Berkeley: University of California Press.

Rawls, J. (1971). A Theory of Justice. Massachusetts: Harvard University Press.

Schermerhorn, J. R., Hunt, J. G., \& Osborn, R. N. (2005). Organizational Behaviour (9th ed.). John Wiley \& Sons, Inc.

Tabitha, W. W., James, G. W., Margaret. W. M., Alice W. K., \& Solomon, M .J. (2013). Managing Workplace Workforce Diversity: A Kenyan Perspective. International Journal of Business and Social Science. 4(16), 199-218.

Yatin, S. F. M., Hamid, H. A., Shah, J. R. K. M., \& Hassan, Z. (2018). Digital Era: New Trends in Information Agencies. International Journal of Academic Research in Progressive Education and Development, 7(3), 150-160.

Shbeilat, M. K., Al Harasees, M. N. (2018). Do Listed Companies Need an IFRS Committee Beside Audit Committee, International Journal of Academic Research in Accounting, Finance and Management Sciences 8 (2): 8-18. 